Competition among schools and educational quality: Tension between various objectives of educational policy

Autores:

Felipe Gajardo

Nicolás Grau 


\title{
Competition among schools and educational quality: Tension between various objectives of educational policy ${ }^{1}$
}

Felipe Gajardo

Universidad de Chile

Nicolás Grau

Economics Department, Universidad de Chile and COES - Centre for Social Conflict and Cohesion Studies.

\begin{abstract}
Using Chilean data for fourth grade students, this research studies the effect of competition among schools on the results of standardized tests, academic self-esteem and motivation, the climate within the school, civic participation and training, and healthy lifestyle habits. In order to address the potential bias due to the endogeneity of the competition among schools, an instrumental variable approach is implemented, using instruments associated with the size of each "educational market." The results show that an increase of one standard deviation in competition among schools generates a moderate increase in standardized test results $(0.06$ standard deviations) and a more significant decrease in the other indicators of quality (between 0.02 and 0.16 standard deviations). Therefore, the results suggest a tension in the school between various objectives of educational policy, in which pressure to improve standardized test scores resulting from competition among schools could produce an undesired effect of deterioration in other dimensions of quality.
\end{abstract}

Keywords: School quality; voucher system; standardized tests.

\footnotetext{
1 The authors would like to thank Alejandra Falabella, Daniel Hojman and Juan Pablo Valenzuela for their comments and suggestions. Nicolás Grau would like to acknowledge funding from the Center for Conflict and Social Cohesion (CONICYT/FONDAP/15130009).
} 


\section{Introduction}

There is a rich discussion regarding the relevance of market incentives in the field of educational policies. ${ }^{2}$ Since Friedman published his seminal work (1962), promoters of these policies have argued that competition for enrollment among schools, and for subsidies when there is a voucher system, would put pressure on schools to make their best effort to improve their quality. The Chilean case has attracted special interest because, since the early 1980s, the country has maintained an educational system in which, by design, market dynamics play a key role in the assurance of educational quality. ${ }^{3}$

The literature on Chile and other countries has not reached a consensus regarding the effects of competition among schools on educational achievement. ${ }^{4}$ However, all of these studies define educational quality in terms of results on standardized tests. Although some studies have considered the effects on other aspects, such as school segregation (Hsieh and Urquiola, 2006) or the increase in school coverage (Bravo et al., 2010), the literature with a quantitative focus has not addressed the effect of market dynamics on other aspects of educational quality and the possible tension between these aspects and standardized tests.

The goal of this article is to contribute to filling this gap. Specifically, we address the effect of competition among schools, measured as the percentage of schools in each district that are subsidized private schools, on a wide range of indicators of educational quality. As in the literature that focuses on the impact of competition on standardized tests, our empirical strategy addresses the potential bias in the estimates due to the endogeneity of the level of competition among schools, using a set of instrumental variables that are related to the size of the potential demand that the schools face in each district. Failing to correct for this endogeneity could lead us to confuse the effect of competition on all these aspects of

\footnotetext{
2 For a good summary of this discussion, see Epple et al. (2015).

3 McEwan and Carney, 2000; Hsieh and Urquiola, 2003; 2006; Gallego, 2002; 2006; Auguste and Valenzuela, 2005.

4 For the Chilean case, there are articles that state that competition does not have an effect other than zero (McEwan and Carney, 2000; Hsieh and Urquiola, 2003; 2006). Others state that it would have a statistically significant and positive effect of moderate magnitudes (Gallego, 2002; 2006; Auguste and Valenzuela, 2005). In regard to evidence for other countries, Bettinger (2011) is noteworthy, reviewing comparative evidence between Colombia, Chile and Sweden, and concluding that there is mixed evidence that strongly depends on the institutional specificities of each nation. For the case of Colombia, it is worth noting a few articles (Angrist et al. 2002, Angrist et al. 2006) that identify a positive effect on standardized tests of the implementation of a voucher program focused on an at-risk sector of Colombian enrollment (around 10\% of enrollment).
} 
educational quality with the effect of unobserved variables, such as parent involvement, on those measurements.

Having a broader and more diverse approach to defining educational quality is especially important when the various measurements of educational quality are not highly correlated with one another. Otherwise, there would be no issue with focusing our analysis on one aspect of quality, as the literature does. Table 1 shows the correlation between the various measures of educational quality that we use in this article. As we can see, although all of these indicators present a positive correlation, standardized tests (in the case of Chile, the SIMCE tests) have a high correlation as a group and a fairly minor correlation with other measures, particularly with healthy lifestyle habits and civic participation and training. Given these levels of correlation, educational policy should anticipate that, if its incentives are mainly focused on improved performance on standardized tests, this will not necessarily imply improvements in the other indicators. In fact, as we will show in this article, there is evidence that the improvements on those tests may come at a cost for the other aspects of educational quality.

Table 1. Statistical correlation between SIMCE results and other quality indicators

\begin{tabular}{|l|c|c|c|c|c|c|}
\hline & $\begin{array}{c}\text { Self-esteem } \\
\text { and } \\
\text { motivation }\end{array}$ & $\begin{array}{c}\text { School } \\
\text { climate }\end{array}$ & $\begin{array}{c}\text { Citizen } \\
\text { participation } \\
\text { and education }\end{array}$ & $\begin{array}{c}\text { Healthy } \\
\text { lifestyle } \\
\text { habits }\end{array}$ & $\begin{array}{c}\text { Mathematics } \\
\text { SIMCE }\end{array}$ & $\begin{array}{c}\text { Reading } \\
\text { SIMCE }\end{array}$ \\
\hline Self-esteem and motivation & 1 & & & & & \\
\hline School climate & 0,29 & 1 & & & & \\
\hline $\begin{array}{l}\text { Citizen participation and } \\
\text { education }\end{array}$ & 0,26 & 0,59 & 1 & & & \\
\hline Healthy lifestyle habits & 0,25 & 0,38 & 0,41 & 1 & & \\
\hline Mathematics SIMCE & 0,24 & 0,26 & 0,11 & 0,05 & 1 & 1 \\
\hline Reading SIMCE & 0,23 & 0,26 & 0,10 & 0,04 & 0,69 & 1 \\
\hline
\end{tabular}

Source: Generated by the authors based on 2013 SIMCE results and data from the Quality and Context of Education Survey for 2013, applied to fourth grade students, teachers, parents, and guardians.

Our empirical strategy is implemented using census data from the Chilean school system (for 2013) for fourth grade students. The results of our estimates, which combine simple linear regressions and least square estimates in two stages, show a clear difference between the 
impact of competition based on standardized tests and the impact of competition on other measurements of educational quality. In the case of our most reliable estimates (which instrument competition), an increase in competition of one standard deviation could increase SIMCE results by 0.06 of a standard deviation, which is consistent with the results in the literature. However, the results also show that competition reduces all other quality indicators: the academic self-esteem and school motivation indicator decreases by 0.02 of a standard deviation, the school climate indicator by 0.1 of a standard deviation, the civic participation and training indicator by between 0.06 and 0.09 of a standard deviation, and the healthy lifestyle habit indicator by between 0.08 and 0.16 of a standard deviation.

The main contribution of this article is that, to the best of our knowledge, it is the first quantitative study of the impact of competition among schools on aspects of educational quality other than standardized tests. It is worth noting that the research is conducted in the Chilean context, which represents a case study that is extremely interesting because it implemented a market logic in the educational field three decades ago. Our results are consistent with the qualitative evidence available for Chile, which has documented a tension between improving standardized tests and promoting more comprehensive development of students as a result of the market dynamics and public policies (Falabella and Opazo, 2014).

This article is structured as follows: The second section offers a discussion of the role of standardized tests and their impact on the incentives that schools face. Section 3 outlines the various aspects of educational quality that are considered in this study. In Section 4, we describe our database. Section 5 develops the empirical strategy implemented in this study. In Section 6, we discuss the main results of this research, and finally, in Section 7, we present our conclusions.

\section{The Chilean school system: Incentives and the role of standardized tests}

The Chilean school system has a structure in which market dynamics play a preponderant role in the promotion of educational quality (Bellei and Vanni, 2015). In theory, this promotion would be ensured by the on-demand funding system (vouchers), to the extent that parents decide their children's schools based on the quality of each entity. As a form of 
reinforcing this accountability based on the market, a set of institutions and public policies have been developed in Chile to ensure that certain minimum quality standards are met.

In Chile, both the market dynamics and quality control mechanisms, conducted through various State institutions, have given special importance to a limited and controversial definition of educational quality, namely the standardized test in the form of the SIMCE. ${ }^{5}$ In the case of the market dynamics, this is explained by factors such as the importance of these tests in the public imaginary, as a result of press coverage and schools' marketing strategies, which determines that the SIMCE plays a role in parents' decisions. In the case of quality control mechanisms, the results of the standardized tests have a direct impact on the schools because there is a set of public policies that assign rewards and sanctions mainly on the basis of those tests. For example, the SNED program gives greater weight to the SIMCE results when it identifies high performing schools compared to institutions with similar characteristics, which in turn determines the amount of the monetary compensation that is granted to teachers (Contreras and Rau, 2012).

In this way, either based on parents' decisions and their resulting impact on school funding or through the direct action of public policy, Chilean schools are pressured to improve standardized test results, even when this comes at the cost of other notions of educational quality which do not have the same weight in the incentives structure that schools and their communities confront.

As a result of this system of incentives, some schools have developed bad practices. For example, the Ministry of Education's 2003 report mentions undesired practices deployed by schools such as curriculum reduction privileging disciplines that are assessed; a predilection for assessment practices that are coherent with the SIMCE format; the concentration of the best teachers at the testing level; and discrimination against students through the selection of those that perform well and social segmentation of the education system (Ministry of Education, 2003). Furthermore, a qualitative study of seven Chilean schools conducted by Falabella and Opazo found evidence of schools using resources from Quality Assurance

\footnotetext{
5 Standardized tests have been used for quite some time in the Chilean school system. The School Performance Assessment Program (PER) was created in 1982, when a standardized test became available to assess school performance. The Educational Quality Measurement System (SIMCE), the standardized test that is still used in Chile today, was introduced in 1988.
} 
Policies, mainly to meet the requirements that the State sets in order to improve their SIMCE results (Falabella and Opazo, 2014).

From the perspective of micro-economics, the model of problems of agency with multiple tasks (Dewatripont, Jewit and Tirole, 2000) allows one to interpret the conflict of incentives that a school faces between only improving performance on standardized tests and other areas. If someone who is interested in promoting quality -the principal- only considers standardized test results to allocate resources such as the SNED, the schools -the agent- will confront explicit incentives that will make it prefer to act negligently, by dedicating the largest number of hours to preparing students for a standardized test rather than spending that time on improving other aspects of educational quality. As Dewatripont, Jewit and Tirole (2000) note, faced with the power of the incentives that the principal grants, the agent will leave aside tasks that provide less compensation, which in this case are the other aspects of educational quality.

The multiple tasks model and the cases of bad practices employed by schools shed light on a possible tension between the results of standardized tests and other quality indicators. Section 5 addresses the identification strategy that this study uses to find empirical evidence of the effect of competition on the SIMCE results and other quality indicators, and verify the existence of the aforementioned tension.

\section{Aspects of educational quality}

The United Nations Children's Fund (UNICEF) proposes five main aspects of teaching and learning: student characteristics, context, available resources, the teaching and learning process and results (UNICEF, 2000).

The student characteristics refer to the aptitude, perseverance, willingness to be educated, prior knowledge and obstacles to learning. Context considers economic, socio-cultural and religious factors, national standards, public resources available for education, competitiveness of the teaching profession in the job market, parent support, peer effects, and other aspects. Available resources refers to teaching and learning materials, facilities and infrastructure, human resources such as teachers and principals and school 
administration. The teaching and learning process refers to learning time, teaching methods, assessment, information and incentives and class size. Finally, results on standardized tests considers basic skills in reading, writing, arithmetic and practical aptitudes for daily learning, creative and emotional skills, values and social advantages (UNICEF, 2000).

A policy that systematically addresses these aspects would provide the tools necessary for a student to fully reach their potential in cognitive and emotional terms, and in regard to their creative capacities. As such, a good public policy for educational quality should include these aspects.

With the creation of the Education Quality Agency in $2011,{ }^{6}$ Chile made a concrete effort to study educational quality beyond the standardized test result aspect. The institution proposed eight indicators for quality: academic self-esteem and school motivation; school climate; civic participation and training; healthy lifestyle habits; retention and drop-out rates; professional technical training; and gender. The first four are personal and social development indicators. They focus on aspects other than the standardized test results, and complement the way in which educational quality has been measured in Chile. This study will pay special attention to these personal and social development indicators.

While these indicators have already been implemented, their impact on public policy decisions is limited to a weight of up to $33 \%$ of the results that the Education Quality Agency uses to rate schools. In other words, decisions to allocate resources in order to improve educational quality continue to be mainly based on the measurement of levels of achievement of the SIMCE standardized test and gives less weight to the considerable richness of other quality indicators. In fact, a school can lose its official recognition if it fails to meet the Learning Standards for four years and is classified as a school with inefficient performance. However, performance on other quality indicators cannot be used, as SNAC Law Article 31 states, as the basis for this decision.

\footnotetext{
6 The National Quality Assurance System (SNAC) for Preschool, Elementary and Secondary Education was installed in 2011. It seeks to implement a series of indicators called "other educational quality indicators" that measure aspects other than standardized test results (Ministry of Education, 2014).
} 


\subsubsection{Academic Self-Esteem and Motivation}

Academic self-esteem and motivation play a key role in quality of life, mental health and levels of wellbeing of students. Self-esteem is deeply linked to feeling loved, accompanied and important to others and oneself. When a student has positive self-esteem, he or she is comfortable with themselves, completes tasks optimistically and accepts successes and errors (Milicic, 2001).

There is also evidence that suggests that students with a higher level of motivation and commitment to what they are taught learn more than those with a purely practical commitment, meaning that they follow the rules and complete the tasks assigned without having any real interest in them (OECD, 2010).

Studies show that active involvement in the learning process increases when the subject feels competent, that is, when they are confident about their own abilities and have high expectations of self-efficacy, value the tasks, are motivated and feel responsible for the learning objectives (Durlak et al., 2011). As such, school behavior cannot be understood without understanding the students' perceptions of themselves, specifically their perceptions of their own academic competency (Esnaola, 2008).

For the Education Quality Agency, this indicator considers, for example, self-perception and self-assessment of students in regard to their ability to learn and perceptions and attitudes about learning and academic achievement (Education Quality Agency, 2016). As such, it is aligned with the student characteristics aspect considered by UNICEF.

\subsubsection{School Climate}

School climate is the community members' perception of interpersonal relations and the general functioning of the institution (National School Climate Center, 2012). The literature on the topic considers variables such as security (rules and feeling of physical and psychological safety of community members), relationships among members of the community (regarding diversity, collaboration, trust and support), teaching-learning environment (support provided to students, cleanliness and orderliness of the classroom), and the institutional environment (organizational structure, leadership, commitment, professional relationships) (National School Climate Center, 2012). 
The evidence shows that the development of a good climate is positive for student wellbeing and as the foundation for the development of social capital and opportunities for understanding among the various members of society $(\mathrm{OPECH}, 2006)$.

The Education Quality Agency states that the school climate includes environments of respect, organization and safety and the way in which key agents interact: students, teachers and parents and guardians (Education Quality Agency, 2016). Environment refers to respectful treatment among members of the educational community, valuing diversity and the absence of discrimination. The second environment considers the existence of clear rules that are known to and respected by everyone and the predominance of constructive dispute resolution methods. Finally, the third environment considers the perceptions of participants regarding the level of security and physical and psychological violence within the school and the existence of prevention mechanisms and action. These components align with the context and available resources aspects that UNICEF promotes.

\subsubsection{Civic Participation and Training}

Civic participation and training are necessary values and lessons for shared life. They allow students to learn the skills, attitudes and virtues necessary for democratic coexistence (Ministry of Education, 2014). Through the progressive exercise of their rights and responsibilities, students have the opportunity to learn among others, respect others and share responsibility for the cooperative climate that forms part of democratic life (Gutmann, 1999).

Democratic participation may allow students to acquire new abilities (organization, planning, dispute resolution, decision-making), develop or reinforce attitudes that favor autonomy (discipline, responsibility, reflection, motivation) and receive praise from peers, influencing the development of the student's personality (OECD, 2003).

The Education Quality Agency defines civic participation and training of students, parents and guardians on the basis of the level at which the institution promotes participation, and the commitment of members of the educational community and the students' perceptions of the way in which democratic life is promoted (Education Quality Agency, 2016). As such, this indicator is aligned with the context and teaching-learning process aspects that UNICEF promotes. 


\subsubsection{Healthy lifestyle habits}

The promotion of active and healthy lifestyle habits is a minimum requirement of education at all levels under the General Education Law (LGE) of Chile. As such, it is key for ensuring the delivery of a quality education that promotes students' comprehensive development (Ministry of Education, 2014).

These habits are defined as the customs, attitudes and modes of behavior that people exhibit when facing daily situations that lead to the formation and consolidation of behavior and learning guidelines that are maintained over time and favorably or unfavorably impact an individual's general wellbeing (Ministry of Education, 2014). There is a close relationship between a person's health and their lifestyle, which is mainly conditioned by food, level of physical activity and self-care (World Health Organization, 2006).

Various scholars have indicated that the effect of an active life is related to more efficient learning (Trudeau \& Shepard, 2008). There is also evidence that healthy lifestyles are related to lower absenteeism and drop-out rates, lower frequency of disruptive behavior and a greater sensation of academic self-efficacy (Story et al., 2009).

The Education Quality Agency connects healthy lifestyle habits to the level at which the school promotes eating habits, an active lifestyle (promoting physical activity and an active lifestyle) and self-care (the level at which risky behaviors are prevented, including sexual behaviors and consumption of tobacco, alcohol and drugs, and promotion of self-care and hygiene), which are beneficial to student health (Education Quality Agency, 2016), aligning with the UNICEF student characteristics aspect.

Personal and social development indicators capture important elements of aspects that go beyond the lessons generated by standardized tests. This study seeks to enrich research on educational quality considering these other aspects that the literature on competition and quality have not addressed.

\section{Data}

This article draws on various sources of information. In order to measure student performance on standardized tests, the 2013 SIMCE results are used for both mathematics 
and language. The SIMCE is a census-style standardized test that is taken at various grade levels. In this study we focus on the test taken by fourth grade students.

In order to build the other quality indicators, the 2013 Educational Context and Quality Questionnaires are used. This survey is conducted by the Education Quality Agency during the week that students throughout the country take the SIMCE tests. The survey consists of a series of questions that allow for self-reporting by students, parents and guardians, and teachers. The questionnaires allow researchers to build the academic self-esteem and motivation, academic climate, civic participation and training and healthy lifestyle habits indicators. This source also provides socio-economic data on the students' families.

The construction of the competition measurement at the district level is based on data from the Official Directory of Schools, published in 2013 by the Ministry of Education. The directory provides data on the type of school (public, private subsidized or paid private). This information is then compared to the Education Context and Quality questionnaire data to obtain the proportion of enrollment of students who attend each schools.

The construction of the instrumental variables of this article require different sources of information. For facts on urban development, data from the aforementioned directory was used. For facts on the district population, data from the National Statistics Institute was used. Table 2 presents descriptive statistics on the variables utilized. The SIMCE data present a standard deviation of approximately 50 points. Average years of education of the fourth grade students' parents was around 12 years, with a standard deviation of 4.28 for the fathers and 3.58 for the mothers. The mean of the household income algorithm was 12.73 . The competition variable has a mean of 0.54 . This means that, on average, $54 \%$ of the schools in a district are subsidized private schools. The standard deviation of this variable is 0.2 . In regard to instrumental variables, the mean of the district enrollment of fourth grade students is 1,836 students, with a district population of 171,334 inhabitants. The percentage of schools located in urban areas is $89 \%$. 
Table 2. Descriptive statistics of key variables

\begin{tabular}{ccccc}
\hline \hline Variable & Mean & St. Dev. & Min & Max \\
\hline SIMCE mathematics & 255.28 & 50.8 & 82 & 395 \\
SIMCE language & 264.25 & 49.5 & 115 & 378 \\
Years of education of fathers of grade 4 students & 12.75 & 4.28 & 0 & 21 \\
Years of education of mothers of grade 4 students & 12.94 & 3.58 & 0 & 21 \\
Household income logarithm & 12.73 & 0.95 & 10.81 & 14.73 \\
Competition (percentage of private subsidized & 0.54 & 0.20 & 0 & 0.97 \\
school enrollment of total Grade 4 enrollment for the & & & & \\
district) & $1,836.86$ & 1508.13 & 1 & 5.983 \\
District enrollment of Grade 4 students & 171,334 & 143,852 & 199 & 594,244 \\
District population & 0.89 & 0.17 & 0 & 1 \\
Urbanization rate & 70.43 & 13.79 & 0 & 100 \\
Academic self-esteem and motivation indicator & 75.39 & 12.28 & 8.5 & 99.86 \\
School climate indicator & 74.79 & 16.30 & 0 & 100 \\
Civic participation and training indicator & 66.32 & 15.13 & 0 & 100 \\
Healthy lifestyle habit indicator & & & & \\
\hline \hline
\end{tabular}

Source: Developed by the authors based on 2013 SIMCE data, the Official Directory of Schools for 2013, Educational Quality and Context Questionnaires for 2013 and the National Statistics Institute.

\section{Empirical strategy}

As we have stated, the main challenge of the studies that have examined the effect of competition among schools on standardized tests is the endogenous nature of competition. This endogeneity is due to the fact that the opening of a school is a decision that is influenced by the characteristics of the students, parents and existing schools in the area, among other things. The problem of identification emerges because some of these characteristics may not be observed by the researcher and could affect the entry of new schools and students' academic performance at the same time.

In order to address this econometric challenge, in addition to OLS -a method whose validity is based on the fact that we observe key variables that simultaneously determine the entry of new schools and student academic performance-, a model is implemented that uses instrumental variables to estimate the effect of competition on various measures of 
educational quality. That empirical strategy can be described by the following two equations, which are estimated in two stages:

$$
\begin{aligned}
& y_{i}^{s d}=\beta C_{k}^{s d}+\gamma X_{i}+\varepsilon_{i} \\
& C_{k}^{s d}=\delta Z_{k}+\theta X_{k}+\epsilon_{k}
\end{aligned}
$$

Where $y_{i}^{s d}$ is an indicator of the quality for the school that student $i$ attends, and may be the SIMCE score or another educational quality indicator; $C_{i}^{s d}$ is the variable of competition among schools, measured as the percentage of private subsidized schools over the total enrollment for district $k ;^{7} X_{i}$ is a vector of control variables which includes the parents' education; the logarithm of household income; socio-economic characteristics of the student's school, such as average years of education of parents and guardians and the logarithm of average household income; socio-economic characteristics of the district such as average years of education of families in the district and the logarithm of the average household income; and the school type. Additionally, $Z_{k}$ represents one of the instrumental variables for district $k$ (or an index combining them). Our instruments are commonly used in the literature: total enrollment of the district (VI 1), logarithm of the district population (VI 2), and the urbanization rate (VI 3). Finally, $\varepsilon_{i}$ and $\epsilon_{k}$ are unobserved variables of each equation.

In the context of this model, the problem of identificationin the case of OLS emerges because the correlation between $\varepsilon_{i}$ and $\epsilon_{k}$ implies that $E\left[\varepsilon_{i} \mid C_{k}^{s d}, X_{i}\right] \neq 0$. At the same time, the identification of the local causal effect of competition on different measures of quality is ensured when estimating with instrumental variables to the extent that $\delta \neq 0$ (condition of relevance) and $E\left[\varepsilon_{i} \mid X_{i}, Z_{k}\right]=0$ (condition of exogeneity). ${ }^{8}$ While the first condition is easy to verify and we review it in the results section, the latter cannot be tested directly.

Although the condition of relevance can be verified directly, it is useful to discuss the mechanisms by which the correlation between the instruments and level of competition in each district operates. In this regard, as Gallego (2002) has indicated, this relationship

\footnotetext{
7 The measurement of competition is commonly used in the literature. Some authors have introduced slight variations, such as Gallego (2006), who uses the ratio of subsidized private schools over public schools. However, overall, the measurement is maintained.

${ }^{8}$ On the notion of the local causal effect and assumptions of identification, see Imbens and Angrist (1994).
} 
develops because the smaller areas in terms of potential students - due to a low number of students or because the geographic area limits their mobility-, the entry of potential competitors is low. This is what explains the relevance of the instruments that are related to the population size of the district and those related to the level of urban development.

In regard to the second condition, it is reasonable to think that the population size of the district or level of urban development do not directly affect the quality of the schools conditioned upon the socio-economic characteristics of the district, but that they only have a role through their indirect impact via the increase in inter-school competition. Suporting this assumption is the fact that the amount of resources per student allocated to improving educational quality does not depend on the size of the market but mainly on the central government or socio-economic level of the district. In the same way, teacher salaries and their clear impact on school quality are not related to the size of the market, because their salary is reasonably similar regardless of where they teach (Auguste and Valenzuela, 2005).

One possible additional problem of the empirical strategy comes from the fact that although they face some restrictions, parents choose where their child will study. This generates a significant sorting process, which leads to a correlation of the characteristics (observable and unobservable) of the students with the characteristics (observable and unobservable) of the schools. However, given that elementary students will probably study in the schools in the districts where they live (over $70 \%$ do so), using districts as a unit of analysis allows us to avoid the problem of selection bias associated with the parents' decision. By contrast, the specifications that use students or schools as a unit of analysis do not address this problem. In this way, although the specifications whose unit of analysis presents a lower level of aggregation (students or schools) allow the richness of the data to be better utilized, controlling for a series of characteristics of the individuals or the schools, those specifications run the risk of being biased given the non-random assignment of students in the various schools.

All in all, possible critiques of our empirical strategy should note that what is innovative about our work is the study of the impact of competition among schools on educational quality indicators other than standardized tests, but that we do this without innovating on empirical strategies which, for the case of Chile, have been used to measure the impact of 
competition on standardized tests. On the one hand, the selection of instrumental variables follows Gallego (2002) to define (VI 1), Hsieh and Urquiola (2003) by using (VI 2), and Gallego (2002), Hsieh and Urquiola (2003) and Auguste and Valenzuela (2005), by incorporating (VI 3). On the other hand, the models are estimated considering the various units of analysis that the literature has developed to study the effect of competition on SIMCE performance: students (i) (Gallego, 2006); schools (j) (McEwan and Carnoy, 1998; Gallego, 2002); and districts ( $k$ ) (Hsieh and Urquiola, 2003; Auguste and Valenzuela, 2005).

In view of the above, a set of models is estimated that differ only in the dependent variable and unit of analysis used. Dependent variables include SIMCE results (simple average of the mathematics and language tests), the four personal development and social development indicators, separately, and the simple average of the four (OIC). All of these add up to six models, and four different units of analysis are used in each, yielding 24 models. ${ }^{9}$

As we will see in the next section, the main result of this article is very robust for the various specifications. This confirms the adequacy of our empirical strategy, given the diversity of instruments and units of analysis of the specifications.

\section{Results}

In this section we discuss our results based on the OLS estimates and estimates conducted using instrumental variables.

The results of the OLS estimates show a clear difference between the impact of competition on standardized tests and the other measures of educational quality. As Table 8 shows, for various levels of aggregation, competition does not show statistically significant effects on standardized tests, presenting negative and positive point estimates. On the contrary, as Tables 9-12 show, the OLS estimates of the impact of competition on other quality indicators generally reveal negative and statistically significant values, particularly for specifications

\footnotetext{
9 The fourth unit of analysis considers the districts, but also covers 35 districts of Greater Santiago in a single market. This strategy is in keeping with the work conducted by Hsieh and Urquiola (2003) and Auguste and Valenzuela (2005).
} 
with lower levels of aggregation (students and schools) with specific estimates between 0 and -0.05 standard deviations. ${ }^{10}$

In regard to the estimates that use instrumental variables, it is pertinent to study the results of the first stage to discuss the explanatory capacity of the instruments and thus avoid the problem of weak instruments. In this regard, Table 13 allows one to review the relevance of the instruments by presenting the Fischer test of the first stage for each one of them. As one can observe, when we use students or schools as the unit of analysis, all of the instruments present test F over the values set by Stock and Yogo (2005), and certainly over 10 (a threshold commonly considered in the literature). If we instead focus on the district as the unit of analysis, in its two specifications, only total student enrollment and district population present test $\mathrm{F}$ in values that allow us to trust the second stages of those estimates.

In this way, the instrumental variables used in this article which are related to "market size" meet the relevancy requirement as instrumental variables, though the urbanization ratio has a test $\mathrm{F}$ that is low for the highest level of district aggregation. ${ }^{11}$

As a result of this, the effect that the increase in competition has on educational quality is studied below, using our three instrumental variables: total enrollment in the district, district population and urbanization rate, when students and schools are used as a unit of analysis; and only the first two when districts are used, given that in that case the urbanization rate loses its relevance.

Table 8 provides information regarding the effect that the increase of competition would have on SIMCE scores. In this regard, and in line with the literature that has focused on the case of Chile (Gallego, 2002; 2006; Auguste and Valenzuela, 2005), there are positive and small effects of competition on standardized tests. Specifically, one can observe that an increase of one standard deviation in the level of district competition generates an increase of 0.06

\footnotetext{
${ }^{10}$ For a different sample, Gallego (2002) finds that without correcting for endogeneity, the effect of a standard deviation of competition reduces the SIMCE results by 0.02 and 0.04 standard deviations. These results are maintained in Gallego (2006) and are aligned with those presented by Auguste and Valenzuela (2005).

${ }^{11}$ Although they analyze different years (separated by more than a decade), it is useful to compare these results to the 2005 study by Auguste and Valenzuela. The outcomes coincide in part with those found by said authors, who determined that the VI District population works as a relevant instrumental variable. In regard to the urbanization ratio instrument, the authors agree that this would be a weak instrument when the district aggregation level is used, but we disagree with them when student and school aggregation level is used, given that this does meet the relevance requirement.
} 
standard deviations in the SIMCE. This is very stable for the various specifications and their respective units of analysis. ${ }^{12}$

These estimates suggest that if the districts moved from their current average of $54 \%$ of the total enrollment of students attending private subsidized schools to $75 \%$, this would cause an increase of approximately 0.05 to 0.06 standard deviations ( 2.5 to 3 points) on the SIMCE test.

As we stated above, these results are in line with the literature, though lower in magnitude. Gallego (2002) found that an increase of one standard deviation in competition increases the SIMCE results at the school level between 0.03 and 0.18 standard deviations. In a later study conducted at the student level, Gallego (2006) found results pointing in the same direction, reporting magnitudes that range from 0.13 to 0.17 standard deviations. Auguste and Valenzuela (2005) found that at the district level an increase in competition of one standard deviation increases standardized test scores by 0.1 standard deviations. Using a different strategy, Contreras and Macias (2002) reported that an increase of one standard deviation on the Herfindhal Hirschmann index increases the results by 0.08 and 0.17 standard deviations. In regard to the effect of competition on the other educational quality indicators, our various specifications clearly show a negative and statistically significant impact of competition on educational quality, measured through these indicators. At the same time, the magnitudes of said outcomes are generally greater than those found for the case of impact on standardized tests.

Tables 9-12 show the impact of competition on various quality measurements. If we focus on the specification that considers the three instruments, we observe that (1) an increase of one standard deviation in competition would reduce the academic self-esteem and motivation indicator by 0.02 standard deviations, considering students and schools as units of analysis and (2) an increase of one standard deviation in competition would reduce the school climate indicator by 0.1 standard deviations, using students and schools as units of analysis. In both cases, the effect is not statistically significant if the unit of analysis is the district. We also observe that (3) an increase of one standard deviation in competition would reduce the

12 The value of the parameters estimated for control variables was not included due to space constraints, but those tables can be requested from the authors. 
participation and civic training indicator by between 0.06 and 0.09 standard deviations, using students, schools and districts as units of analysis. Finally, (4) an increase of one standard deviation in competition would reduce the healthy lifestyle habits indicator by between 0.08 and 0.16 standard deviations and would be statistically significant for all units of aggregation.

These results show that all personal and social development indicators would suffer a negative effect if competition were to increase by one standard deviation. The healthy lifestyle habits indicator would have the greatest impact followed by school climate, participation and civic training and academic self-esteem and motivation.

Table 14 shows that if we take a simple average of the four indicators, a one standard deviation increase in competition would have a negative and statistically significant effect of between 0.06 and 0.13 standard deviations on that aggregate indicator, which would summarize the quality measurements other than standardized tests considered in this study.

Given that competition is a phenomenon that is mainly developed in urban areas (Gallego, 2002; Auguste and Valenzuela, 2005), Table 15 presents a summary of the same estimates discussed above only for urban populations. The results support the existence of a positive and statistically positive and moderate effect of competition on the SIMCE as well as a negative and statistically significant effect on the other quality indicators. In fact, in this case, the effects found at the aggregate level for districts are statistically significant, which suggests that the inclusion of rural districts in the analysis makes the effect of competition dissipate.

\section{Conclusions}

It is necessary to evaluate the impact of public policies in education from a broader perspective that is not restricted to the results of standardized tests. This study provides inputs for this, analyzing the effect of competition among schools on educational quality indicators other than standardized tests. It is important to note that the analysis is conducted using data for Chile, a country that stands out on the world stage for having a market-based educational system, with $90 \%$ of the schools financed using vouchers, which has been in place for over 30 years. 
We established a set of educational quality indicators, including academic self-esteem and motivation; school climate; participation and civic training; and healthy lifestyle habits. OLS and Two-Stage Least Squares were used to measure the effect of competition on standardized tests and on the other quality indicators described above. In order to correct for endogeneity between the level of competition and the outcome variables, we used three instrumental variables that are commonly used in the literature on the impact of competition on standardized tests, namely, total enrollment in the district, (a logarithm of) district population, and the urbanization rate. In addition, models were estimated using various levels of aggregation: students, school and district. The latter was used to ensure the robustness of the results for the sorting dynamics within each district.

The results show that an increase of one standard deviation in competition (using all of the instrumental variables) raises SIMCE results at the student, school and district levels, by 0.05 to 0.06 of a standard deviation. However, this increase in competition also implies a reduction in all of the other quality indicators: 0.02 of a standard deviation in the academic self-esteem and motivation indicator; 0.10 of a standard deviation in the school climate indicator; 0.06 to 0.09 of a standard deviation in the participation and civic training indicator; and 0.08 to 0.16 of a standard deviation on the healthy lifestyle habits indicator.

The results of this article suggest that competition among schools for students (and, through them, for funding) could generate a certain level of tension in schools between improving their standardized test results and focusing on other aspects of educational quality. ${ }^{13}$ This tension is particularly relevant in contexts such as Chile, in which all public policies and public debate, including articles in the news, revolve around the results of the schools on those standardized tests.

Overall, the results should be considered carefully because, although the instrumental variables are aligned with those used by national and international literature, these studies have focused on the effect of competition among schools on standardized tests, and the

13 Another possible tension is described by Cuesta et al. (2006), who document how pressure to obtain better scores on standardized tests in Chile can cause some schools to seek out ways to prevent students with low performance from attending class on the day that the tests are given. 
quality of the instruments in that context does not assure their quality in our case, where school quality is measured in a different way. 


\section{References}

Agencia de Calidad de la Educación (2016). Los Indicadores de desarrollo personal y social en los establecimientos educacionales chilenos: una primera mirada.

Angrist, J., Bloom, E., King, E., y Kremer, M. (2002) Vouchers for Private Schooling in Colombia: Evidence from a Randomized Natural Experiment. American Economic Review, 92 (5), 1535-1558.

Angrist, J., Bettinger, E., y Kremer., M. (2006) Long-Term Educational Consequences of Secondary School Vouchers: Evidence from Administrative Records in Colombia. The American Economic Review, 96, pp. 847-862.

Auguste y Valenzuela J., (2005). Do students benefits from school competition? Evidence from Chile.

Bellei C. y Vanni X. (2015). The evolution of educational policy in Chile, 1980-2014. En Education in South America (2015), Schwartzman (editor), Bloomsbury Publishing.

Bettinger, E. (2011). Handbook of the Economics of Education, Vol. 4, Access Online via Elsevier.

Bravo, D., Mukhopadhyay, S. y Todd, P. E. (2010), Effects of school reform on education and labor market performance: Evidence from Chile's universal voucher system. Quantitative Economics, 1: 47-95.

Campaña Alto al Simce (2014). Propuesta: Nuevo Sistema de Evaluación para la Educación Escolar. Documento para la discusión. Santiago, Chile

Contreras D. y Macias V. (2002). Competencia y resultados educacionales. Mimeo, Universidad de Chile.

Contreras D. y Rau, T. (2012). Tournament Incentives for Teachers: Evidence from a ScaledUp Intervention in Chile, Economic Development and Cultural Change, University of Chicago Press, vol. 61(1), 219-246.

Cuesta J., González, F. y Larroulet, C. (2016) Distorted Quality Signals in School Markets. 
Dewatripont M., Jewitt I., y Tirole J. (2000). Multitask agency problems: Focus and task clustering. European Economic Review 44 (2000) 869-877,

Durlak, J. Weissberg, R. Schellinger, K. Dymnicki, A. \& Taylor, R. (2011) The Impact of Enhancing Students' Social and Emotional Learning: A Meta-Analysis of School-Based Universal Interventions. Child Development, January/February 2011, Volume 82, Number 1, Pages 405-432.

Epple D. y Romano R. (1998). Competition between Private and Public schools, Vouchers, and Peer-group Effects. American Economic Review 88 (1): 33-62.

Epple D., Romano R., y Urquiola M. (2015). School Vouchers: A survey of the economic literature. NBER Working Paper Series.

Esnaola, I. (2008). El autoconcepto: perspectivas de investigación. Revista de Psicodidáctica, $13(1), 179-194$.

Hsieh C., y Urquiola M., (2003). When schools compete, How do they compete? An assessment of Chile's nationwide school voucher program. NBER Working Paper 10008.

Hsieh C., y Urquiola M., (2006). The effects of generalized school choice on achievement and stratification: Evidence from Chile's voucher program. Journal of Public Economics 90 (2006) 1477-1503.

Imbens, G., y Angrist, J. (1994). Identification and Estimation of Local Average Treatment Effects. Econometrica, 62(2), 467-475.

Falabella y Opazo (2014). Sistema de Aseguramiento de la Calidad y procesos de mejoramiento: una mirada desde la gestión educativa. Centro de Investigación y Desarrollo de la Educación. Universidad Alberto Hurtado.

Friedman, M. (1962) Capitalism and Freedom, University of Chicago press.

Gallego F., (2002). Competencia y Resultados Educativos: Teoría y Evidencia para Chile. Documento de Trabajo $\mathrm{N}^{\circ} 150$, Banco Central de Chile.

Gallego F., (2006). Voucher-School Competition Incentives, and Outcomes: Evidence from Chile. 
Gutmann, A. (1999) Democratic Education. With a new preface and epilogue. Princeton University press. Princeton, New Jersey.

McEwan P. y Carnoy M. (1999). The impact of competition on Public school quality: Longitudinal evidence from Chile's Voucher system. Manuscrito, School of Education. Stanford University.

Ministerio de Educación (2014). Fundamentos. Otros Indicadores de Calidad Educativa. Unidad de Currículum y Evaluación. Ministerio de Educación. Santiago, Chile.

Milicic, N. (2001). Creo en ti: La construcción de la autoestima en el contexto escolar. Santiago: Editorial LOM.

National School Climate Center (2012) School Climate. Recuperado el 23 de junio de 2015, de http://www.schoolclimate.org/climate/

Larrañaga O. (2010). Las nuevas políticas de protección social en perspectiva histórica. Programa de las Naciones Unidas para el Desarrollo, PNUD.

OECD (2003). Student Engagement at School: A Sense of Belonging and Participation. Results from PISA 2000. Paris: OECD.

OECD (2010). PISA 2009 Results: What Makes a School Successful? Resources, Policies and Practices (Volume IV), OECD Publishing.

OPECH (2006). SIMCE: Balance Crítico y Proyecciones Imprescindibles. Documento de Trabajo 1 del Observatorio Chileno de Políticas Educativas, Universidad de Chile.

Stock J., y Yoko M. (2005). Testing for Weak Instruments in Linear IV Regression. Identification and inference for econometric models: Essays in honor of Thomas Rothenberg. Story, M., Nanney, M. \& Schwartz, M. (2009). Schools and Obesity Prevention. The Milbank Quarterly, 87(1): 71-100.

Trudeau, F. \& Shepard, R. (2008). Physical education, school physical activity, school sports and academic performance. International Journal of Behavioral Nutrition and Physical Activity, 5(10), 1-12.

UNICEF (2000). Defining Quality Education. Working Paper Series. New York, USA. 


\section{Appendix}

\section{A. Quality Indicators}

The agency publishes the methodology used to build the indicators, but these indicators are not disseminated for each student. As such, the present study builds the other quality indicators based on the agency's statements using data from the Education Quality and Context Questionnaires for Grade 4 students in 2013.

The Education Quality Agency proposes building personal and social development indicators through the Main Components Factorial Analysis methodology (Ministry of Education, 2014). This methodology is based on the idea that each variable can be broken down into two factors: a common factor and a unique factor.

$$
X_{i}=a_{i} F+d_{i} U_{i}
$$

Where $F$ is the common factor and $U_{i}$ is the unique factor. The common factor $F$ contains the part of the variability that is common to all variables, while $U_{i}$ contains the part of the variability that we cannot explain based on the common factor. The methodology seeks to capture the common factor $F$, allowing researchers to identify which questions should be considered in the various personal and social development indicators.

Based on the Education Context and Quality Questionnaires for students, parents and guardians, and teachers, a pool of questions is selected for each personal and social development indicator which have as common factors certain aspects of each indicator. ${ }^{14}$ In the Annexes section, there are questions selected using the factorial analysis methodology (see Tables 3, 4, 5 and 6), the aspects that compose each indicator, according to the agency, and which respondents consider each indicator (see Table 7). In regard to the latter, both the academic self-esteem and motivation and healthy lifestyle habits consider questions that were answered only by students. The school coexistence climate indicator considers questions that students, parents and guardians, and teachers answered. The civic participation and training indicator covers questions answered by students and teachers.

\footnotetext{
${ }^{14}$ In the construction of the other quality indicators, each is composed of certain aspects. These are not to be confused with the aspects that comprise the definition of educational quality.
} 
Each one of the questions selected by Factorial Analysis is adjusted so that all point in a positive direction. ${ }^{15}$ The responses are re-scaled on a range of 0 to 100 points. The goal of this step is for the answers to be placed on the same scale for all quality indicators. The intermediate values of the scale will depend on the number of possible answers to each question. For example, a question based on a range of five responses will be re-scaled to a range of $0,25,50,75$ and 100 .

Once all of the questions selected by aspect of each indicator are set, a simple average of the responses of each student is taken at the factor level. Next, a simple average for the factors of each student at the aspect level is taken. Finally, the results obtained at the aspect level are averaged to calculate the individual score in the indicator. When the questions are asked of students, parents and guardians, and teachers, the weights that the agency sets are used.

For the report on the results, the Education Quality Agency uses a score of less than 50 on the indicator to signal negative performance. If the score is between 50 and 83 points, the result is considered to be average. If the score is above 83 , the indicator is found to have a positive development. The exception is the academic self-esteem and motivation indicator, which is considered to have a positive result with a score of over 50 points (Ministry of Education, 2014).

Table 3. Questions considered for the academic self-esteem and motivation indicator

For Students:

\begin{tabular}{|c|c|}
\hline $\begin{array}{l}\text { Self-percep } \\
\text { learn }\end{array}$ & $\begin{array}{l}\text { Perceptions and attitudes of students towards } \\
\text { learning and academic achievement }\end{array}$ \\
\hline $\begin{array}{l}\text { - I have a hard time concentrating and paying } \\
\text { attention in class. } \\
\text { - } \quad \text { I learn more easily than the rest of my peers. } \\
\text { - } \quad \text { I am intelligent. } \\
\text { - } \quad \text { I can speak in front of the class. } \\
\text { - } \quad \text { I generally remember what I learn. } \\
\text { - } \quad \text { I learn languages quickly and easily. } \\
\text { - } \quad \text { I do well in languages. } \\
\text { - I am good at physical education. } \\
\text { - I can do all of the exercises in physical } \\
\text { education well. }\end{array}$ & $\begin{array}{l}\text { - } \quad \text { am happy with my grades. } \\
\text { - } \quad \text { I have fun studying. } \\
\text { - } \quad \text { I ask the teacher when I don't understand } \\
\text { something in class. } \\
\text { - } \quad \text { I always do my homework. } \\
\text { - } \quad \text { I do my homework even when the tasks are } \\
\text { difficult. } \\
\text { - When I am grown up, I will achieve every } \\
\text { goal I set for myself. } \\
\text { I give up easily when I have a hard time in } \\
\text { a class. }\end{array}$ \\
\hline
\end{tabular}

15 If the question is posed in negative terms, the scoring of the scale is inverted. 
- I can do all of the mathematics exercises well.

- I am good at art.

- $\quad$ I do all of the art exercises well.

Source: Developed by the authors based on the Education Quality and Context questionnaires for Grade 4, 2013.

\section{Table 4. Questions considered for the school climate indicator}

For Students:

\begin{tabular}{|c|c|c|}
\hline $\begin{array}{l}\text { Presence of a respectful } \\
\text { environment in school }\end{array}$ & $\begin{array}{l}\text { Presence of an organized } \\
\text { environment in school }\end{array}$ & $\begin{array}{l}\text { Presence of a safe environment in } \\
\text { school }\end{array}$ \\
\hline $\begin{array}{l}\text { - } \quad \text { We treat each other well. } \\
\text { - } \quad \text { My teachers respect us. } \\
\text { - } \text { wudents treat each other } \\
\text { well in my school. } \\
\text { - My teachers make me } \\
\text { feel loved. } \\
\text { - The principal makes me } \\
\text { feel loved. } \\
\text { - My school is a friendly } \\
\text { place that I like to go to. } \\
\text { My classmates make } \\
\text { sure the classroom is } \\
\text { clean. } \\
\text { My classmates make } \\
\text { sure that the school is } \\
\text { clean (bathrooms, } \\
\text { fields). } \\
\text { They write on the walls. }\end{array}$ & 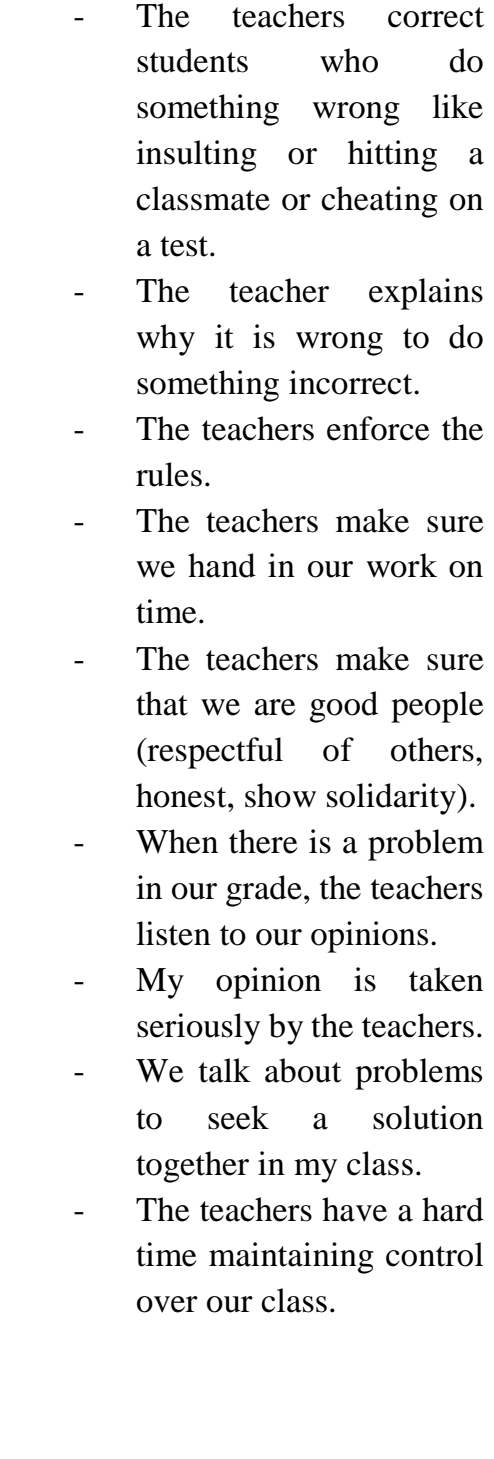 & 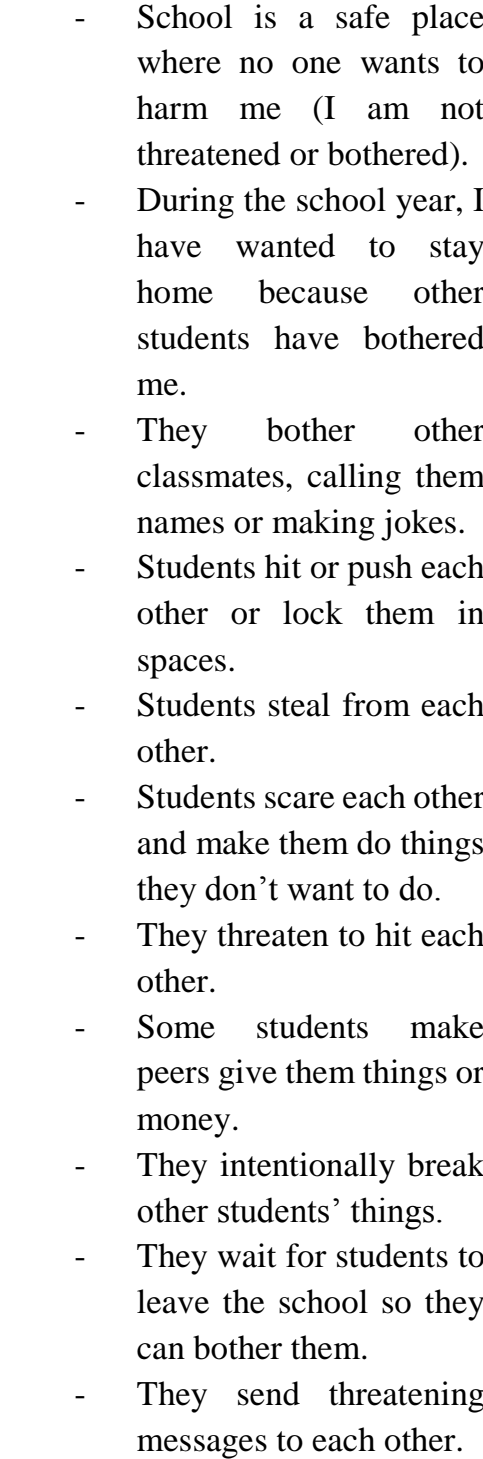 \\
\hline
\end{tabular}




\begin{tabular}{|l|l|l|}
\hline & & $\begin{array}{l}\text { They make fun of each } \\
\text { other based on their } \\
\text { physical characteristics } \\
\text { or other characteristics } \\
\text { (weight, skin color, etc.) }\end{array}$ \\
\hline
\end{tabular}

Source: Developed by the authors based on the Education Quality and Context questionnaires for Grade 4, 2013.

For Teachers:

\begin{tabular}{|c|c|c|}
\hline $\begin{array}{l}\text { Presence of a respectful } \\
\text { environment in the school }\end{array}$ & $\begin{array}{l}\text { Presence of an organized } \\
\text { environment in the school }\end{array}$ & $\begin{array}{l}\text { Presence of a safe environment in } \\
\text { the school }\end{array}$ \\
\hline $\begin{array}{l}\text { - Students treat the } \\
\text { teachers with respect. } \\
\text { - Students listen to their } \\
\text { peers respectfully. } \\
\text { - There are fights among } \\
\text { students that interrupt } \\
\text { class. } \\
\text { - It is very hard to start } \\
\text { class because the } \\
\text { students are disorderly. } \\
\text { The teacher interrupts } \\
\text { class to quiet or punish } \\
\text { students. an in an } \\
\text { Students work in } \\
\text { orderly manner and } \\
\text { follow the teacher's } \\
\text { instructions. } \\
\text { There is a respectful } \\
\text { relationship among the } \\
\text { teachers. } \\
\text { There is a respectful } \\
\text { relationship between } \\
\text { teachers and students. } \\
\text { There is a respectful } \\
\text { relationship between } \\
\text { teachers and the } \\
\text { administration. } \\
\text { It is hard for teachers to } \\
\text { do their work because of } \\
\text { the lack of discipline. } \\
\text { Order and discipline are } \\
\text { respected. } \\
\text { Students keep } \\
\text { classrooms clean. }\end{array}$ & $\begin{array}{l}\text { - The rules of coexistence } \\
\text { or discipline are known } \\
\text { to everyone in the school } \\
\text { community. } \\
\text { - Rules are not always } \\
\text { followed. } \\
\text { - The teachers and } \\
\text { administrators apply the } \\
\text { rules using the same } \\
\text { criteria. } \\
\text { All of the teachers are } \\
\text { aware of the rules for } \\
\text { addressing bullying. } \\
\text { The administrators and } \\
\text { teachers take the } \\
\text { appropriate measures to } \\
\text { handle complaints of } \\
\text { sexual harassment. } \\
\text { The administration } \\
\text { promotes opportunities } \\
\text { to work on and discuss } \\
\text { ways for teachers to } \\
\text { effectively deal with } \\
\text { harassment in school. } \\
\text { There are rules for } \\
\text { addressing sexual } \\
\text { harassment. }\end{array}$ & 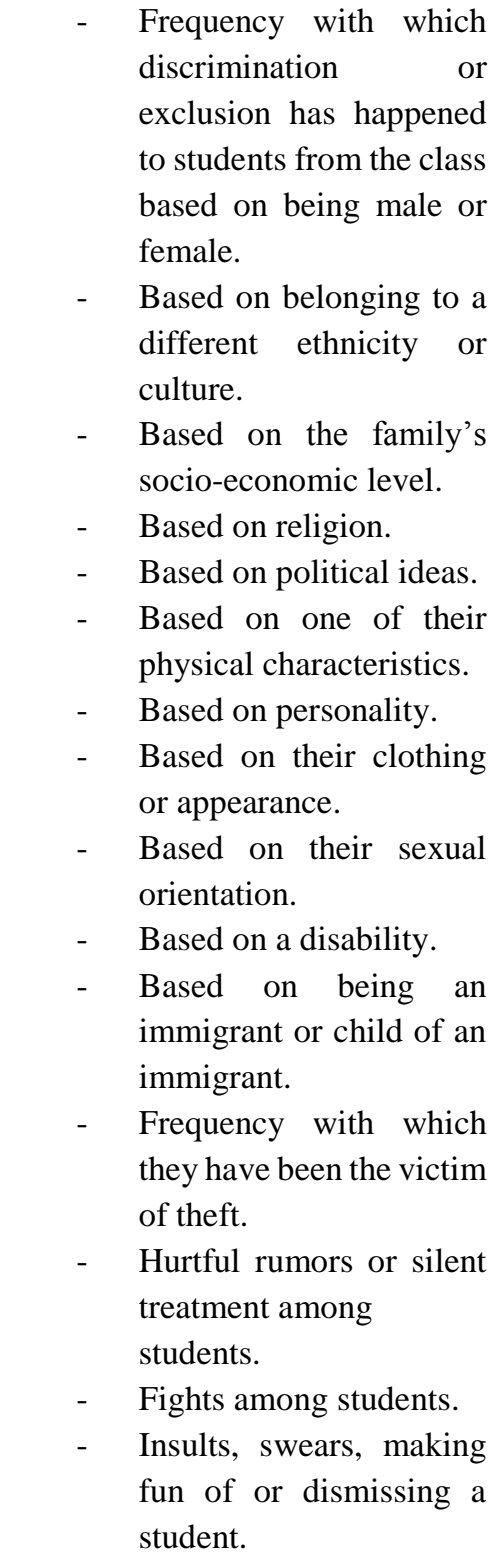 \\
\hline
\end{tabular}




\begin{tabular}{|c|c|}
\hline $\begin{array}{l}\text { - Students take care of the } \\
\text { furniture and school } \\
\text { infrastructure. }\end{array}$ & 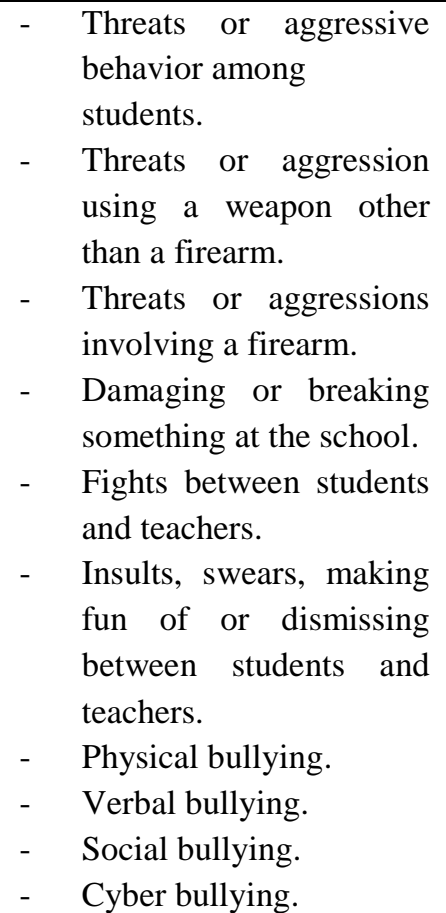 \\
\hline
\end{tabular}

Source: Developed by the authors based on the Education Quality and Context questionnaires for Grade 4, 2013.

For parents and guardians:

\begin{tabular}{|c|c|c|}
\hline $\begin{array}{l}\text { Presence of a respectful } \\
\text { environment at school }\end{array}$ & $\begin{array}{l}\text { Presence of an organized } \\
\text { environment at school }\end{array}$ & $\begin{array}{l}\text { Presence of a safe environment at } \\
\text { school }\end{array}$ \\
\hline $\begin{array}{l}\text { - Values training that the } \\
\text { school provides. } \\
\text { - Student commitment to } \\
\text { the school. } \\
\text { - Care and cleanliness of } \\
\text { the school. }\end{array}$ & $\begin{array}{l}\text { - I am familiar with the } \\
\text { school rules. } \\
\text { - The school rules are } \\
\text { followed. } \\
\text { - Everyone is familiar with } \\
\text { the school's goals. } \\
\text { - The school rules on } \\
\text { bullying among students } \\
\text { have been clearly } \\
\text { established. } \\
\text { The teacher makes an } \\
\text { appointment with me to } \\
\text { discuss the student at } \\
\text { least once per year. } \\
\text { The teacher is available } \\
\text { to respond to my needs } \\
\text { or requests regarding the } \\
\text { student. }\end{array}$ & $\begin{array}{ll}\text { - } & \text { Situations of bullying. } \\
\text { - } & \text { Student safety at school. } \\
\text { - } & \text { Measures have been } \\
\text { taken (punishments, } \\
\text { meetings with parents } \\
\text { and guardians, etc.) in } \\
\text { cases of bullying among } \\
\text { students. } \\
\text { - Information has been } \\
\text { provided to parents and } \\
\text { guardians regarding } \\
\text { preventing and } \\
\text { responding adequately to } \\
\text { bullying among students. } \\
\text { The way in which serious } \\
\text { infractions are handled. }\end{array}$ \\
\hline
\end{tabular}




\begin{tabular}{|l|l|l|}
\hline & $-\begin{array}{l}\text { The school is willing to } \\
\text { receive and hear my } \\
\text { concerns and } \\
\text { suggestions. }\end{array}$ & \\
\hline
\end{tabular}

Source: Developed by the authors based on the Education Quality and Context questionnaires for Grade 4, 2013.

Table 5. Questions considered for the indicator civic participation and training

\section{For Students:}

\begin{tabular}{|c|c|c|}
\hline Sense of belonging & $\begin{array}{l}\text { Participation encouraged by the } \\
\text { school }\end{array}$ & $\begin{array}{l}\text { Presence of a safe environment in } \\
\text { the school }\end{array}$ \\
\hline $\begin{array}{l}\text { - Students participate in } \\
\text { the organization of } \\
\text { school activities } \\
\text { (ceremonies, } \\
\text { presentations, trips, etc.). }\end{array}$ & $\begin{array}{l}\text { Fun activities organized } \\
\text { by the school (bingo, } \\
\text { parties, competitions, } \\
\text { etc.). } \\
\text { Cultural activities } \\
\text { organized by the school } \\
\text { (plays, art exhibits, etc.) } \\
\text { - Service activities } \\
\text { organized by the school } \\
\text { (fundraisers, food } \\
\text { donations, planting trees, } \\
\text { etc.). } \\
\text { Athletic activities } \\
\text { organized by the school. }\end{array}$ & $\begin{array}{l}\text { - The teachers ask us for } \\
\text { our opinion in class. } \\
\text { - When there is a problem } \\
\text { in class, the teachers } \\
\text { listen to our opinions. } \\
\text { - The teachers consider } \\
\text { my opinion. } \\
\text { - In my class, we talk } \\
\text { about problems in order } \\
\text { to find a solution. }\end{array}$ \\
\hline
\end{tabular}

Source: Developed by the authors based on the Education Quality and Context questionnaires for Grade 4, 2013.

For parents and guardians:

\begin{tabular}{|l|c|c|}
\hline & Participation by the school & \\
\hline & $-\quad$ There is a parents' center & \\
& $-\quad$ at the school. \\
& Recreational activities. & \\
\hline
\end{tabular}




\begin{tabular}{|l|l|}
\hline- & Athletic activities. \\
- & Academic and cultural \\
& activities. \\
- & Solidarity campaigns. \\
- & Commemorative \\
& activities. \\
- & The information that the \\
& school provides to \\
& parents and guardians. \\
& The school's willingness \\
& to meet with and listen to \\
parents and guardians. & \\
\hline
\end{tabular}

Source: Developed by the authors based on the Education Quality and Context questionnaires for Grade 4, 2013.

Table 6. Questions considered for the healthy lifestyle habits

For students:

\begin{tabular}{|c|c|c|}
\hline Eating habits & Active lifestyle habits & Self-care habits \\
\hline 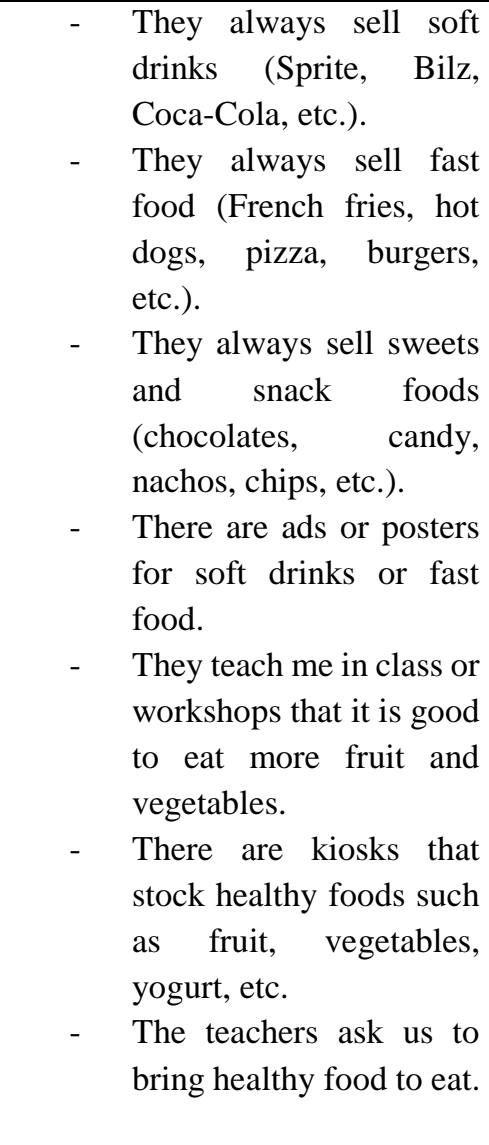 & 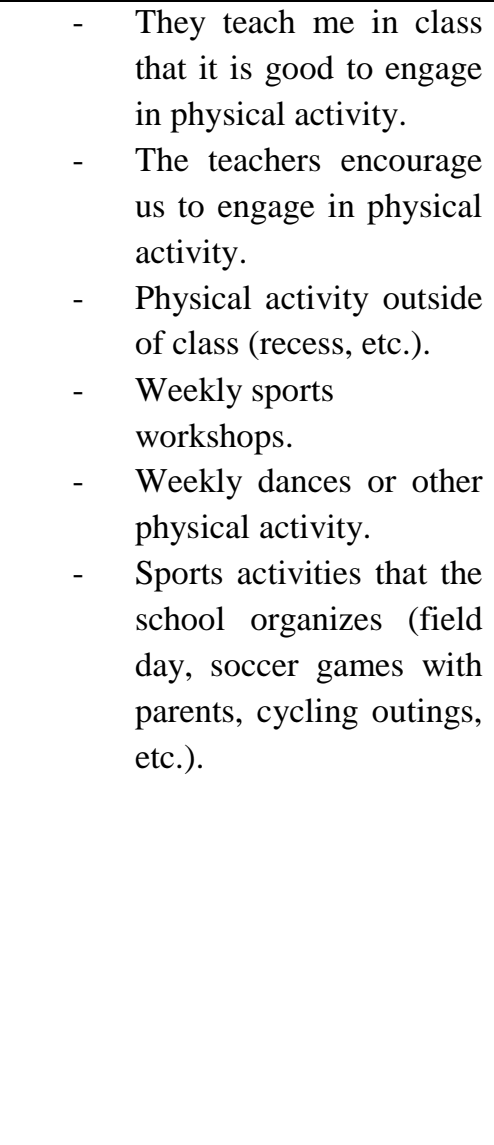 & 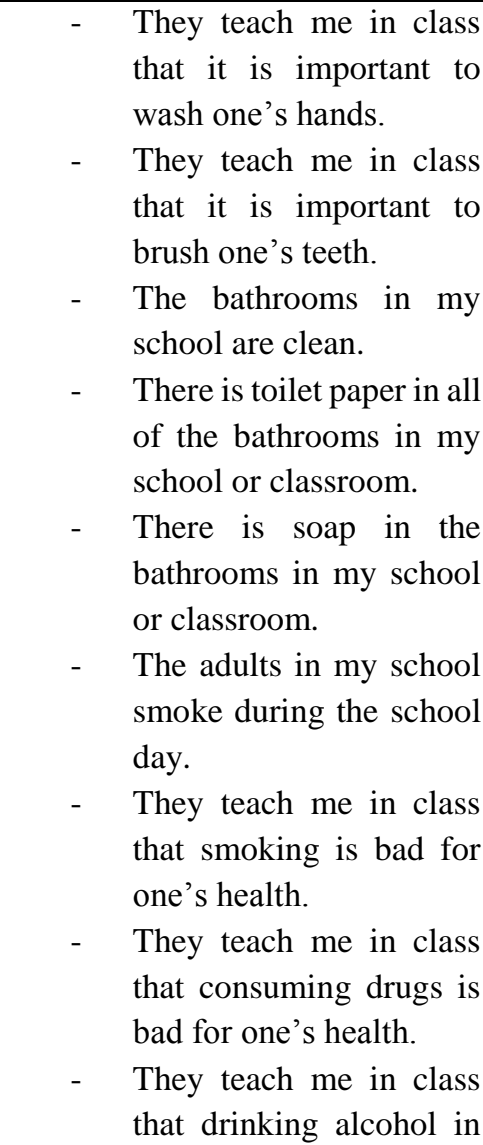 \\
\hline
\end{tabular}




\begin{tabular}{|l|l|l|}
\hline & & $\begin{array}{l}\text { excess is bad for my } \\
\text { health. }\end{array}$ \\
\hline
\end{tabular}

Source: Developed by the authors based on the Education Quality and Context Questionnaire data for Grade 4, 2013.

Table 7. Indicators of personal and social development and their aspects by interview

\begin{tabular}{|c|c|c|c|c|}
\hline Indicators & Respondent & \multicolumn{3}{|c|}{ Dimensions } \\
\hline Academic self-esteem and motivation & Students & Motivation & $\begin{array}{r}\text { Academic se } \\
\text { ass }\end{array}$ & $\begin{array}{l}\text { oerception and } \\
\text { ment }\end{array}$ \\
\hline \multirow[t]{3}{*}{ School climate } & Students & $\begin{array}{c}\text { Respectful } \\
\text { environment }\end{array}$ & $\begin{array}{c}\text { Organized } \\
\text { environment }\end{array}$ & $\begin{array}{c}\text { Safe } \\
\text { environment }\end{array}$ \\
\hline & Teachers & $\begin{array}{c}\text { Respectful } \\
\text { environment }\end{array}$ & $\begin{array}{c}\text { Organized } \\
\text { environment }\end{array}$ & $\begin{array}{c}\text { Safe } \\
\text { environment }\end{array}$ \\
\hline & $\begin{array}{l}\text { Parents and } \\
\text { guardians }\end{array}$ & $\begin{array}{c}\text { Respectful } \\
\text { environment }\end{array}$ & $\begin{array}{c}\text { Organized } \\
\text { environment }\end{array}$ & $\begin{array}{c}\text { Safe } \\
\text { environment }\end{array}$ \\
\hline \multirow[t]{2}{*}{ Participation and civic training } & Students & $\begin{array}{c}\text { Sense of } \\
\text { belonging }\end{array}$ & Participation & $\begin{array}{c}\text { Democratic } \\
\text { life }\end{array}$ \\
\hline & $\begin{array}{l}\text { Parents and } \\
\text { guardians }\end{array}$ & - & Participation & - \\
\hline Healthy lifestyle habits & Students & Eating habits & $\begin{array}{c}\text { Active } \\
\text { lifestyle } \\
\text { habits }\end{array}$ & $\begin{array}{l}\text { Self-care } \\
\text { habits }\end{array}$ \\
\hline
\end{tabular}

Source: Developed by the authors based on the Education Quality Agency (2013).

Appendix: Methodology for building other quality indicators

In regard to the strategy of averaging the results obtained at the aspect level, the proposal from the Education Quality Agency was used:

In the case of academic self-esteem and motivation: 


$$
\text { indicator }_{j}^{a m}=\frac{\sum \text { Dimension }_{e j}^{a m}}{E_{j}}
$$

Where $e$ is the student from grade $j$, which is Grade 4 for this study. The super index am is related to academic self-esteem and motivation. $E_{j}$ is the total number of students who answered the Education Quality and Context Questionnaire 2013.

In the case of school coexistence climate:

$$
\text { indicator }_{e j}^{c}=\frac{\sum \text { Dimension }_{e j}^{c}}{E_{j}}
$$

Where $e$ is the student from grade $j$, which is Grade 4 for this study.

$$
\text { indicator }_{p j}^{c}=\frac{\sum \text { Dimension }_{p j}^{c}}{P_{j}}
$$

Where $p$ is the teacher of grade $j$, which is Grade 4 for this study, and $P_{j}$ is the total number of teachers who answered the Education Quality and Context Questionnaire 2013.

$$
\text { indicator }_{a j}^{c}=\frac{\sum \text { Dimension }_{a j}^{c}}{A_{j}}
$$

Where $a$ is the parent or guardian for grade $j$, which is Grade 4 for this study, and $A_{j}$ is the total number of parents and guardians who answered the Education Quality and Context Questionnaire in 2013.

Next, to calculate the school climate indicator for Grade 4, the students, teachers and parents, and guardians' answers are added and weighted per the suggestion of the Education Quality Agency, or:

$$
\text { Indicator }_{j}^{c}=0.5 * \text { indicator }_{e j}^{c}+0.4 * \text { indicator }_{a j}^{c}+0.1 * \text { indicator }_{p j}^{c}
$$

The agency justifies these differentiated weights because, first, the teachers are proportionally fewer than the students and parents, and guardians and; second, because the teachers have a conflict of interest given that their performance is indirectly evaluated with these measurements (Ministry of Education, 2014).

For participation and civic training: 


$$
\text { indicator }_{e j}^{p f}=\frac{\sum \text { Dimension }_{e j}^{p f}}{E_{j}}
$$

where $e$ is the student from grade $j$, which is Grade 4 for this study.

$$
\text { indicator }_{a j}^{p f}=\frac{\sum \text { Dimension }_{a j}^{p f}}{A_{j}}
$$

where $a$ is the teacher for the grade $j$, which is Grade 4 for this study, and $A_{j}$ is the total number of parents and guardians who answered the questionnaire.

Next, the Education Quality Agency considers the following differentiated weights to calculate the participation and civic training indicator:

$$
\text { Indicator }_{j}^{p f}=0.5 * \text { indicator }_{e j}^{p f}+0.5 * \text { indicator }_{a j}^{p f}
$$

Finally, the case of healthy lifestyle habits:

$$
\text { indicator }_{e j}^{h}=\frac{\sum \text { Dimension }_{e j}^{h}}{E_{j}}
$$

Where $e$ is the student in grade $j$ which for our study is Grade 4 , and $E_{j}$ is the total number of students who answered the questionnaire. 


\section{B. Results}

Table 8. Effect of competition on SIMCE results

\begin{tabular}{|c|c|c|c|c|}
\hline \multicolumn{5}{|c|}{ Dependent variable: SIMCE average in standard deviation } \\
\hline Variable & Students & Schools & Districts & $\begin{array}{l}\text { Grouped } \\
\text { Districts }\end{array}$ \\
\hline \multirow[t]{2}{*}{ Competition (OLS) } & -0.004 & -0.005 & 0.007 & -0.007 \\
\hline & $(0.01)$ & $(0.01)$ & $(0.01)$ & $(0.01)$ \\
\hline \multirow[t]{2}{*}{ Competition (VI 1) } & $0.06^{* *}$ & $0.06^{*}$ & $0.08^{* *}$ & $-0.14 * *$ \\
\hline & $(0.03)$ & $(0.03)$ & $(0.04)$ & $(0.07)$ \\
\hline \multirow[t]{2}{*}{ Competition (VI 2) } & $0.06^{* * *}$ & $0.06^{* * *}$ & $0.06 * *$ & -0.06 \\
\hline & $(0.02)$ & $(0.02)$ & $(0.03)$ & $(0.04)$ \\
\hline \multirow[t]{2}{*}{ Competition (VI 3) } & 0.05 & 0.05 & 0.06 & 0.12 \\
\hline & $(0.04)$ & $(0.04)$ & $(0.06)$ & $(0.10)$ \\
\hline \multirow[t]{2}{*}{ Competition (together) } & $0.05 * * *$ & $0.05^{* * *}$ & $0.06 * *$ & -0.003 \\
\hline & $(0.02)$ & $(0.02)$ & $(0.03)$ & $(0.03)$ \\
\hline \multicolumn{5}{|l|}{ Controls } \\
\hline Parents' Education & Yes & No & No & No \\
\hline Household Income Log. & Yes & No & No & No \\
\hline Parents' Education Est. & Yes & Yes & No & No \\
\hline Household Income Log. Est. & Yes & Yes & No & No \\
\hline Parents' Education District & Yes & Yes & Yes & Yes \\
\hline \multicolumn{5}{|l|}{ Household Income Log. } \\
\hline District & Yes & Yes & Yes & Yes \\
\hline School Type & Yes & Yes & No & No \\
\hline Zone & Yes & Yes & Yes & Yes \\
\hline Fischer (together) & 210.9 & 206.1 & 17.5 & 22.7 \\
\hline Override Test (p-value) & 0.00 & 0.00 & 0.00 & 0.00 \\
\hline $\mathrm{N}$ & 167,489 & 7,170 & 338 & 303 \\
\hline R-Squared & 0.14 & 0.47 & 0.65 & 0.39 \\
\hline
\end{tabular}

Notes: Competition (OLS) contemplates a model of Ordinary Least Squares. Competition (VI 1) considers instrumental variables in two stages, using as VI the logarithm of total district enrollment. Competition (VI 2) uses as VI the logarithm of district population and Competition (VI 3) uses as VI the rate of urbanization. Competition (Together) considers VI 1, VI 2 and VI 3 for the units of analysis students and schools, and only the first two for districts due to the loss of relevance of VI 3. Grouped districts includes 35 districts from the Santiago Metropolitan Area in a single market. Regressions corrected for heterogeneity between schools and districts where applicable. Standard robust errors are listed in parentheses. *, ** and *** indicate the level of significance at $10 \%, 5 \%$ and $1 \%$, respectively. 
Table 9. Effect of competition on the academic self-esteem and motivation indicator

\begin{tabular}{|c|c|c|c|c|}
\hline \multicolumn{5}{|c|}{ Dependent variable: Academic self-esteem and motivation in St. Dev. } \\
\hline Variable & Students & Schools & Districts & $\begin{array}{l}\text { Groupec } \\
\text { Districts }\end{array}$ \\
\hline \multirow[t]{2}{*}{ Competition } & $-0.02 * * *$ & $-0.01 * *$ & $-0.02 * *$ & -0.008 \\
\hline & $(0.01)$ & $(0.01)$ & $(0.01)$ & $(0.01)$ \\
\hline \multirow[t]{2}{*}{ Competition (VI 1) } & $-0.06 * * *$ & $-0.06 * * *$ & $-0.05 * * *$ & $-0.04 *$ \\
\hline & $(0.02)$ & $(0.02)$ & $(0.00)$ & $(0.03)$ \\
\hline \multirow[t]{2}{*}{ Competition (VI 2) } & $-0.03 * *$ & $-0.02 * *$ & -0.03 & -0.02 \\
\hline & $(0.01)$ & $(0.02)$ & $(0.02)$ & $(0.02)$ \\
\hline \multirow[t]{2}{*}{ Competition (VI 3) } & -0.02 & -0.02 & -0.02 & 0.05 \\
\hline & $(0.03)$ & $(0.03)$ & $(0.03)$ & $(0.13)$ \\
\hline \multirow[t]{2}{*}{ Competition (together) } & $-0.02 * *$ & $-0.02 *$ & -0.02 & 0.001 \\
\hline & $(0.01)$ & $(0.01)$ & $(0.02)$ & $(0.01)$ \\
\hline \multicolumn{5}{|l|}{ Controls } \\
\hline Parents' Education & Yes & No & No & No \\
\hline Household Income Log. & Yes & No & No & No \\
\hline Parents' Education Est. & Yes & Yes & No & No \\
\hline \multicolumn{5}{|l|}{ Household Income Log. } \\
\hline Est. & Yes & Yes & No & No \\
\hline Parents' Education District & Yes & Yes & Yes & Yes \\
\hline \multicolumn{5}{|l|}{ Household Income Log. } \\
\hline District & Yes & Yes & Yes & Yes \\
\hline School Type & Yes & Yes & No & No \\
\hline Zone & Yes & Yes & Yes & Yes \\
\hline Fischer (together) & 206.5 & 206.1 & 17.5 & 22.7 \\
\hline Override Test (p-value) & 0.00 & 0.00 & 0.00 & 0.00 \\
\hline $\mathrm{N}$ & 167,489 & 7,170 & 338 & 303 \\
\hline R-Squared & 0.01 & 0.04 & 0.11 & 0.05 \\
\hline
\end{tabular}

Notes: Competition (OLS) contemplates an Ordinary Least Squares model. Competition (VI 1) considers instrumental variables in two stages, using as VI the logarithm of total district enrollment. Competition (VI 2) uses as VI the logarithm of district population and Competition (VI 3) uses as VI the rate of urbanization. Competition (together) considers VI 1, VI 2 and VI 3 for the units of analysis students and schools, and only the first two for districts due to the loss of relevance of VI 3. Grouped districts includes 35 districts from the Santiago Metropolitan Area in a single market. Regressions corrected for heterogeneity between schools and districts where applicable. Standard robust errors are listed in parentheses. $* * *$ and $* * *$ indicate the level of significance at $10 \%, 5 \%$ and $1 \%$, respectively. 
Table 10. Effect of competition on the school climate indicator

\begin{tabular}{|c|c|c|c|c|}
\hline \multicolumn{5}{|c|}{ Dependent variable: School climate variable in St. Dev. } \\
\hline Variable & Students & Schools & Districts & $\begin{array}{l}\text { Grouped } \\
\text { Districts }\end{array}$ \\
\hline \multirow[t]{2}{*}{ Competition } & $-0.05 * * *$ & $-0.04 * * *$ & -0.01 & 0.01 \\
\hline & $(0.01)$ & $(0.01)$ & $(0.01)$ & $(0.01)$ \\
\hline \multirow[t]{2}{*}{ Competition (VI 1) } & $-0.17 * * *$ & $-0.16 * * *$ & $-0.11 * * *$ & $-0.13 * *$ \\
\hline & $(0.04)$ & $(0.04)$ & $(0.00)$ & $(0.05)$ \\
\hline \multirow[t]{2}{*}{ Competition (VI 2) } & $-0.09 * * *$ & $-0.08 * * *$ & -0.05 & $-0.07 *$ \\
\hline & $(0.02)$ & $(0.02)$ & $(0.03)$ & $(0.04)$ \\
\hline \multirow[t]{2}{*}{ Competition (VI 3) } & $-0.11 * *$ & $-0.12 * * *$ & -0.06 & 0.05 \\
\hline & $(0.05)$ & $(0.05)$ & $(0.05)$ & $(0.08)$ \\
\hline \multirow[t]{2}{*}{ Competition (together) } & $-0.10 * * *$ & $-0.10^{* * *}$ & -0.03 & -0.02 \\
\hline & $(0.02)$ & $(0.02)$ & $(0.03)$ & $(0.03)$ \\
\hline \multicolumn{5}{|l|}{ Controls } \\
\hline Parents' Education & Yes & No & No & No \\
\hline Household Income Log. & Yes & No & No & No \\
\hline Parents' Education Est. & Yes & Yes & No & No \\
\hline \multicolumn{5}{|l|}{ Household Income Log. } \\
\hline Est. & Yes & Yes & No & No \\
\hline Parents' Education District & Yes & Yes & Yes & Yes \\
\hline \multicolumn{5}{|l|}{ Household Income Log. } \\
\hline District & Yes & Yes & Yes & Yes \\
\hline School Type & Yes & Yes & No & No \\
\hline Zone & Yes & Yes & Yes & Yes \\
\hline Fischer (together) & 210.9 & 206.1 & 17.5 & 22.7 \\
\hline Override Test (p-value) & 0.00 & 0.00 & 0.00 & 0.00 \\
\hline N Students & 167,489 & 7,170 & 338 & 303 \\
\hline R-Squared & 0.08 & 0.29 & 0.27 & 0.19 \\
\hline
\end{tabular}

Notes: Competition (OLS) considers an Ordinary Least Squares model. Competition (VI 1) considers instrumental variables in two stages, using as VI the logarithm of total district enrollment. Competition (VI 2) uses as VI the logarithm of district population and Competition (VI 3) uses as VI the rate of urbanization. Competition (together) considers VI 1, VI 2 and VI 3 for the units of analysis students and schools, and only the first two for districts due to the loss of relevance of VI 3. Grouped districts includes 35 districts from the Santiago Metropolitan Area in a single market. Regressions corrected for heterogeneity between schools and districts where applicable. Standard robust errors are listed in parentheses. $*, * *$ and $* * *$ indicate the level of significance at $10 \%, 5 \%$ and $1 \%$, respectively. 
Table 11. Effect of competition on the civic participation and training indicator

Dependent variable: Civic participation and training in St. Dev.

\begin{tabular}{|c|c|c|c|c|}
\hline Variable & Students & Schools & Districts & $\begin{array}{l}\text { Grouped } \\
\text { Districts }\end{array}$ \\
\hline \multirow[t]{2}{*}{ Competition } & $-0.03 * * *$ & $-0.02 * * *$ & $-0.02 *$ & -0.003 \\
\hline & $(0.01)$ & $(0.01)$ & $(0.01)$ & $(0.01)$ \\
\hline \multirow[t]{2}{*}{ Competition (VI 1) } & $-0.10 * * *$ & $-0.09 * * *$ & $-0.07 * * *$ & $-0.07 * *$ \\
\hline & $(0.03)$ & $(0.03)$ & $(0.00)$ & $(0.03)$ \\
\hline \multirow[t]{2}{*}{ Competition (VI 2) } & $-0.09 * * *$ & $-0.08 * * *$ & $-0.07 * * *$ & $-0.07 * * *$ \\
\hline & $(0.02)$ & $(0.02)$ & $(0.02)$ & $(0.02)$ \\
\hline \multirow[t]{2}{*}{ Competition (VI 3) } & $-0.07 * *$ & $-0.07^{* *}$ & -0.06 & 0.001 \\
\hline & $(0.03)$ & $(0.03)$ & $(0.04)$ & $(0.06)$ \\
\hline \multirow[t]{2}{*}{ Competition (together) } & $-0.09 * * *$ & $-0.09 * * *$ & $-0.07 * * *$ & $-0.06^{* * *}$ \\
\hline & $(0.02)$ & $(0.02)$ & $(0.02)$ & $(0.02)$ \\
\hline \multicolumn{5}{|l|}{ Controls } \\
\hline Parents' Education & Yes & No & No & No \\
\hline Household Income Log. & Yes & No & No & No \\
\hline Parents' Education Est. & Yes & Yes & No & No \\
\hline \multicolumn{5}{|l|}{ Household Income Log. } \\
\hline Est. & Yes & Yes & No & No \\
\hline Parents' Education District & Yes & Yes & Yes & Yes \\
\hline \multicolumn{5}{|l|}{ Household Income Log. } \\
\hline District & Yes & Yes & Yes & Yes \\
\hline School Type & Yes & Yes & No & No \\
\hline Zone & Yes & Yes & Yes & Yes \\
\hline Fischer (together) & 210.9 & 206.1 & 17.5 & 22.7 \\
\hline Override Test (p-value) & 0.11 & 0.00 & 0.00 & 0.00 \\
\hline $\mathrm{N}$ students & 167.489 & 7.170 & 338 & 303 \\
\hline R-Squared & 0.02 & 0.14 & 0.04 & 0.03 \\
\hline
\end{tabular}

Notes: Competition (OLS) considers an Ordinary Least Squares model. Competition (VI 1) considers instrumental variables in two stages, using as VI the logarithm of total district enrollment. Competition (VI 2) uses as VI the logarithm of district population and Competition (VI 3) uses as VI the rate of urbanization. Competition (together) considers VI 1, VI 2 and VI 3 for the units of analysis students and schools, and only the first two for districts due to the loss of relevance of VI 3. Grouped districts includes 35 districts from the Santiago Metropolitan Area in a single market. Regressions corrected for heterogeneity between schools and districts where applicable. Standard robust errors are listed in parentheses. *,** and *** indicate the level of significance at $10 \%, 5 \%$ and $1 \%$, respectively. 
Table 12. Effect of competition on the healthy lifestyle habits indicator.

Dependent variable: Healthy lifestyle habits in St. Dev.

\begin{tabular}{lcccc}
\hline Variable & Students & School & Districts & Drouped \\
Competition & $-0.04^{* * *}$ & $-0.03^{* * *}$ & $-0.03^{* *}$ & -0.002 \\
& $(0.01)$ & $(0.01)$ & $(0.01)$ & $(0.01)$ \\
Competition (VI 1) & $-0.17^{* * *}$ & $-0.16^{* * *}$ & $0.15^{* * *}$ & -0.02 \\
& $(0.03)$ & $(0.03)$ & $(0.00)$ & $(0.03)$ \\
Competition (VI 2) & $-0.15^{* * *}$ & $-0.15^{* * *}$ & $-0.14^{* * *}$ & $-0.05^{*}$ \\
& $(0.02)$ & $(0.02)$ & $(0.03)$ & $(0.03)$ \\
Competition (VI 3) & $-0.16^{* * *}$ & $-0.16^{* * *}$ & $-0.15^{* *}$ & -0.06 \\
& $(0.04)$ & $(0.04)$ & $(0.05)$ & $(0.07)$ \\
Competition (together) & $-0.16^{* * *}$ & $-0.16^{* * *}$ & $-0.14^{* * *}$ & $-0.08^{* *}$ \\
Controls & $(0.02)$ & $(0.02)$ & $(0.03)$ & $(0.03)$ \\
Parents' Education & & & & \\
Household Income Log. & Yes & No & No & No \\
Parents' Education Est. & Yes & Yes & No & No \\
Household Income Log. Est. & Yes & Yes & No & No \\
Parents' Education District & Yes & Yes & Yes & Yes \\
Household Income Log. & & & & Yes \\
District & Yes & Yes & Yes & Yes \\
School Type & Yes & Yes & No & No \\
Zone & Yes & Yes & Yes & Yes \\
Fischer (together) & & & & \\
Override Test (p-value) & 0.00 & 0.00 & 0.00 & 0.00 \\
N & 167,489 & 7,170 & 338 & 303 \\
R-Squared & 0.01 & 0.03 & 0.05 & 0.03 \\
\hline \hline
\end{tabular}

Notes: Competition (OLS) contemplates an Ordinary Least Squares model. Competition (VI 1) considers instrumental variables in two stages, using as VI the logarithm of total district enrollment. Competition (VI 2) uses as VI the logarithm of district population and Competition (VI 3) uses as VI the rate of urbanization. Competition (together) considers VI 1, VI 2 and VI 3 for the units of analysis students and schools, and only the first two for districts due to the loss of relevance of VI 3. Grouped districts includes 35 districts from the Santiago Metropolitan Area in a single market. Regressions corrected for heterogeneity between schools and districts where applicable. Standard robust errors are listed in parentheses. ${ }^{*}, * *$ and $* * *$ indicate the level of significance at $10 \%, 5 \%$ and $1 \%$, respectively. 
Table 13. Effect of instrumental variables on competition (Stage One)

\begin{tabular}{|c|c|c|c|c|}
\hline \multicolumn{5}{|c|}{ Dependent Variable: Competition in St. Dev. } \\
\hline & & & & Grouped \\
\hline Instrumental Variable & Students & School & Districts & Districts \\
\hline \multirow[t]{4}{*}{ Total student enrollment (VI 1) } & $0.00^{* * *}$ & $0.00^{* * *}$ & $0.00 * * *$ & $0.00^{* * *}$ \\
\hline & $(0.00)$ & $(0.00)$ & $(0.00)$ & $(0.00)$ \\
\hline & [400.3] & {$[400.9]$} & [24.2] & {$[17.8]$} \\
\hline & $\{0.53\}$ & $\{0.53\}$ & $\{0.51\}$ & $\{0.48\}$ \\
\hline \multirow[t]{4}{*}{ (Log.) District population (VI 2) } & $0.42 * * *$ & $0.43^{* * *}$ & $0.45^{* * *}$ & $0.19^{* * *}$ \\
\hline & $(0.00)$ & $(0.00)$ & $(0.00)$ & $(0.00)$ \\
\hline & {$[785.2]$} & {$[805.4]$} & {$[65.85]$} & [29.1] \\
\hline & $\{0.57\}$ & $\{0.58\}$ & $\{0.56\}$ & $\{0.51\}$ \\
\hline \multirow[t]{4}{*}{ Urbanization Rate (VI 3) } & $1.41^{* * *}$ & $1.40^{* * *}$ & $1.46^{* * *}$ & $1.01^{* * *}$ \\
\hline & $(0.02)$ & $(0.02)$ & $(0.02)$ & $(0.02)$ \\
\hline & [99.3] & [99.4] & [8.4] & {$[3.6]$} \\
\hline & $\{0.51\}$ & $\{0.51\}$ & $\{0.49\}$ & $\{0.46\}$ \\
\hline \multicolumn{5}{|l|}{ Controls } \\
\hline Parents' Education & Yes & No & No & no \\
\hline Household Income Log. & Yes & No & No & no \\
\hline Parents' Education Est. & Yes & Yes & No & no \\
\hline Household Income Log. Est. & Yes & Yes & No & no \\
\hline Parents' Education District & Yes & Yes & Yes & Yes \\
\hline Household Income Log. District & Yes & Yes & Yes & Yes \\
\hline School Type & Yes & Yes & Yes & Yes \\
\hline $\mathrm{N}$ & 167,489 & 7,170 & 338 & 303 \\
\hline R-Squared & 0.14 & 0.46 & 0.64 & 0.37 \\
\hline
\end{tabular}

Notes: The first stage corresponds to a linear regression between the competition variable and the instrumental variables, in which VI 1 corresponds to the total district enrollment logarithm, VI 2 corresponds to the district population logarithm and VI 3 corresponds to the urbanization rate. Grouped districts includes 35 districts from the Santiago Metropolitan Area in a single market. Standard robust errors are listed in parentheses. Test F of first stage in brackets. R2 of first stage in parentheses. *,** and $* * *$ indicate the level of significance at $10 \%, 5 \%$ and $1 \%$, respectively. 
Table 14. Effect of Competition in the Indicator 'Other Quality Indicators'

\begin{tabular}{|c|c|c|c|c|}
\hline \multicolumn{5}{|c|}{ Dependent variable: } \\
\hline Variable & Students & School & District & $\begin{array}{l}\text { Grouped } \\
\text { Districts }\end{array}$ \\
\hline \multirow[t]{2}{*}{ Competition } & $-0.05 * * *$ & $-0.03 * * *$ & $-0.03 * *$ & -0.001 \\
\hline & $(0.01)$ & $(0.01)$ & $(0.01)$ & $(0.01)$ \\
\hline \multirow[t]{2}{*}{ Competition (VI 1) } & $-0.17 * * *$ & $-0.16^{* * *}$ & $-0.13 * * *$ & $-0.09 *$ \\
\hline & $(0.03)$ & $(0.03)$ & $(0.00)$ & $(0.04)$ \\
\hline \multirow[t]{2}{*}{ Competition (VI 2) } & $-0.13 * * *$ & $-0.12 * * *$ & $-0.10 * * *$ & $-0.07 * *$ \\
\hline & $(0.02)$ & $(0.02)$ & $(0.03)$ & $(0.03)$ \\
\hline \multirow[t]{2}{*}{ Competition (VI 3) } & $-0.13 * * *$ & $-0.13 * * *$ & $-0.10^{*}$ & 0.01 \\
\hline & $(0.04)$ & $(0.04)$ & $(0.05)$ & $(0.06)$ \\
\hline \multirow[t]{2}{*}{ Competition (together) } & $-0.13 * * *$ & $-0.13 * * *$ & $-0.09 * * *$ & $-0.06^{* *}$ \\
\hline & $(0.02)$ & $(0.02)$ & $(0.02)$ & $(0.03)$ \\
\hline \multicolumn{5}{|l|}{ Controls } \\
\hline Parents' education & Yes & No & No & No \\
\hline Household Income Log. & Yes & No & No & No \\
\hline Est. Parents' Education & Yes & Yes & No & No \\
\hline \multicolumn{5}{|l|}{ Log. Est. Parents' } \\
\hline Education & Yes & Yes & No & No \\
\hline Parents' Education District & Yes & Yes & Yes & Yes \\
\hline \multicolumn{5}{|l|}{ Household Income Log. } \\
\hline District & Yes & Yes & Yes & Yes \\
\hline School Type & Yes & Yes & No & No \\
\hline Zone & Yes & Yes & Yes & Yes \\
\hline Fischer (set) & 210.9 & 206.1 & 17.5 & 22.7 \\
\hline Override Test (p-value) & 0.00 & 0.00 & 0.00 & 0.00 \\
\hline $\mathrm{N}$ students & 167,489 & 7,170 & 338 & 303 \\
\hline R-squared & 0.03 & 0.15 & 0.11 & 0.03 \\
\hline
\end{tabular}

\footnotetext{
Notes: Competition (OLS) contemplates an Ordinary Least Squares model. Competition (VI 1) considers instrumental variables in two stages using as VI the logarithm of total enrollment in the district. Competition (VI 2) uses as VI the logarithm of district population and Competition (VI 3) uses as VI the urban development ratio. Competition (together) considers VI 1, VI 2 and VI 3 for the units of analysis students and schools, and only the first two for districts due to the loss of relevance of VI 3. Districts grouped cover 35 districts from the Santiago Metropolitan Area in a single market. Regressions corrected by intra-school and district heterogeneity as necessary. Standard robust errors are listed in parentheses. $*$, ** and $* * *$ indicate the level of significance at $10 \%, 5 \%$ and $1 \%$, respectively.
} 
Table 15. Effect of competition on the SIMCE and other quality indicators. Only observations from urban areas.

\begin{tabular}{|c|c|c|c|c|c|c|}
\hline Variable & $\begin{array}{l}\text { SIMCE } \\
\text { Average }\end{array}$ & $\begin{array}{l}\text { Self- } \\
\text { esteem, } \\
\text { Academic } \\
\text { Motivation }\end{array}$ & $\begin{array}{l}\text { School } \\
\text { Climate }\end{array}$ & $\begin{array}{l}\text { Civic } \\
\text { Participat. } \\
\text { and Training }\end{array}$ & $\begin{array}{l}\text { Healthy } \\
\text { Lifestyle } \\
\text { Habits }\end{array}$ & $\begin{array}{l}\text { Other Quality } \\
\text { Indicators } \\
\text { (Average) }\end{array}$ \\
\hline \multicolumn{7}{|l|}{ Aggregation: Students } \\
\hline \multirow[t]{3}{*}{ Competition (MLS) } & -0.004 & $-0.02 * * *$ & $-0.06^{* * *}$ & $-0.04 * * *$ & - & $-0.05 * * *$ \\
\hline & & & & & $0.04 * * *$ & \\
\hline & $(0.01)$ & $(0.01)$ & $(0.01)$ & $(0.01)$ & $(0.01)$ & $(0.01)$ \\
\hline \multirow[t]{5}{*}{ Competition (VI Relevant) } & $0.05 * *$ & $-0.04 * * *$ & $-0.10 * * *$ & $-0.11 * * *$ & - & $-0.15 * * *$ \\
\hline & & & & & $0.18 * * *$ & \\
\hline & $(0.02)$ & $(0.01)$ & $(0.03)$ & $(0.02)$ & $(0.02)$ & $(0.02)$ \\
\hline & {$[185.7]$} & {$[185.7]$} & {$[185.7]$} & {$[185.7]$} & {$[185.7]$} & {$[185.7]$} \\
\hline & $\{0.15\}$ & $\{0.01\}$ & $\{0.10\}$ & $\{0.02\}$ & $\{0.01\}$ & $\{0.03\}$ \\
\hline \multicolumn{7}{|l|}{ Aggregation: Schools } \\
\hline \multirow[t]{3}{*}{ Competition (MLS) } & -0.004 & $-0.02 * * *$ & $-0.06^{* * *}$ & -0.04 & - & $-0.05 * * *$ \\
\hline & & & & & $0.04 * * *$ & \\
\hline & $(0.01)$ & $(0.01)$ & $(0.01)$ & $(0.01)$ & $(0.01)$ & $(0.01)$ \\
\hline \multirow[t]{5}{*}{ Competition (VI Relevant) } & $0.05 * * *$ & $-0.04 * * *$ & $-0.09 * * *$ & $-0.10 * * *$ & - & $-0.14 * * *$ \\
\hline & & & & & $0.18 * * *$ & \\
\hline & $(0.02)$ & $(0.01)$ & $(0.03)$ & $(0.02)$ & $(0.02)$ & $(0.002)$ \\
\hline & {$[189.7]$} & {$[189.7]$} & {$[189.7]$} & {$[189.7]$} & {$[189.7]$} & {$[189.7]$} \\
\hline & $\{0.51\}$ & $\{0.06\}$ & $\{0.36\}$ & $\{0.16\}$ & $\{0.01\}$ & $\{0.19\}$ \\
\hline \multicolumn{7}{|l|}{ Aggregation: Districts } \\
\hline \multirow[t]{2}{*}{ Competition (MLS) } & 0.009 & $-0.02 * * *$ & -0.01 & $-0.02 *$ & $-0.04 * *$ & $-0.03 * *$ \\
\hline & $(0.01)$ & $(0.01)$ & $(0.01)$ & $(0.01)$ & $(0.02)$ & $(0.01)$ \\
\hline \multirow[t]{4}{*}{ Competition (VI Relevant) } & $-0.06^{* *}$ & $-0.04 * *$ & $-0.06^{* *}$ & $-0.08 * * *$ & - & $-0.12 * * *$ \\
\hline & & & & & $0.16 * * *$ & \\
\hline & $(0.03)$ & $(0.02)$ & $(0.03)$ & $(0.03)$ & $(0.03)$ & $(0.03)$ \\
\hline & {$[17.5]$} & {$[17.5]$} & {$[17.5]$} & {$[17.5]$} & {$[17.5]$} & {$[17.5]$} \\
\hline
\end{tabular}



$\{0.70\}$
$\{0.13\}$
$\{0.28\}$
$\{0.11\}$
$\{0.11\}$
$\{0.11\}$

Aggregation: Grouped Districts

Competition (MLS)

$\begin{array}{llllll}-0.008 & -0.01 & 0.007 & -0.002 & 0.00 & -0.002\end{array}$

$\begin{array}{llllll}(0.01) & (0.01) \quad(0.01) \quad(0.01) \quad(0.01) \quad(0.01)\end{array}$

Competition (VI Relevant)

$\begin{array}{llllll}-0.04 & -0.02 & -0.05 & -0.08^{* * *} & -0.08^{* *} & -0.08^{* *} \\ (0.04) & (0.02) & (0.04) & (0.02) & (0.03) & (0.03) \\ {[9.64]} & {[9.64]} & {[9.64]} & {[9.64]} & {[9.64]} & {[9.64]} \\ \{0.39\} & \{0.08\} & \{0.14\} & \{0.14\} & \{0.05\} & \{0.05\}\end{array}$

Notes: The number of students is 167,489 . The number of schools is 7,170 . The number of urban districts is 313 . The number of urban districts considering the Metropolitan Santiago Area as a single district is 279. Competition (MLS) is based on a Minimum Least Squares model. Competition (VI) considers instrumental variables in two stages using as VI the set of logarithm of total enrollment of the district, district population logarithm, and the development ratio for the units of analysis students and schools. The first two only were used for districts due to the loss of relevance of the third. Grouped districts covers 35 Metropolitan Santiago districts into a single market. Control variables were parents' education and student, school and district household income, as well as type of school. The level of significance is listed in parentheses. The F-test is listed in brackets and the R2 is listed in parentheses. Regressions corrected for intra-school and district heterogeneity based on each case. Robust standard errors in parentheses. *,**, and *** indicate the level of significance at $10 \%, 5 \%$ and $1 \%$, respectively. 